\title{
Factors Affecting the Activity and Synthesis of NAD-dependent Lactate Dehydrogenase in Rhizopus oryzae
}

\author{
By G. G. PRITCHARD \\ Department of Chemistry, Biochemistry and Biophysics, Massey University, \\ Palmerston North, New Zealand
}

(Received 6 March 1973)

\begin{abstract}
SUMMARY
The NAD-dependent lactate dehydrogenase of Rhizopus oryzae, like some bacterial lactate dehydrogenases, catalyses reduction of pyruvate by NADH but not the reverse reaction. It will, however, catalyse reduction of the $\mathrm{NAD}^{+}$analogue, 3-acetylpyridine adenine dinucleotide $\left(\mathrm{APAD}^{+}\right)$by $\mathrm{L}(+)$-lactate; $\mathrm{NAD}^{+}$does not inhibit the rate of $\mathrm{APAD}^{+}$reduction in this reaction. The relationship between pyruvate reductase activity and NADH concentration is sigmoidal with a high apparent $K_{m}$ for NADH $\left(2.9 \times \mathrm{IO}^{-4} \mathrm{M}\right)$.

Enzyme level reaches a peak during early vegetative growth of the mycelium and declines rapidly before sporulation. The peak level reached is dependent on the glucose concentration of the medium, being greatest in high glucose media. When grown in media containing growth-limiting concentrations of glucose, lactate dehydrogenase activity is negligible. Transfer of such mycelia to high glucose media results in a rapid increase in the specific activity of the enzyme; this increase is prevented by cycloheximide. High levels of lactate dehydrogenase can also be induced by growing the fungus in media containing growth-limiting concentrations of zinc.
\end{abstract}

\section{INTRODUCTION}

The lactate dehydrogenases from several Oomycete fungi and from the Chytridiomycete Allomyces have been described recently (Gleason, Nolan, Wilson \& Emerson, I966; Gleason \& Price, I969; LeJohn, 197I ; Purohit \& Turian, 1972). However, little work has been done on the lactate dehydrogenases from the other major group of lactic acid-forming fungi belonging to the Zygomycete genus Rhizopus. Obayashi et al. (1966) partially purified L-lactate dehydrogenase from Rhizopus oryzae and reported that the enzyme catalyses both pyruvate reduction and lactate oxidation. A more recent study of this species (Pritchard, 1971) indicated that the NAD-dependent lactate dehydrogenase functions only in the direction of pyruvate reduction thus resembling the lactate dehydrogenases of some bacteria (Wittenberger \& Fulco, I967; Tarmy \& Kaplan, I968). The oxidation of lactate was shown to be due to an NAD-independent lactate dehydrogenase which is active only in the later stages of growth in contrast to the NAD-dependent enzyme which is active in young presporulating mycelia.

The present study was undertaken to provide a more detailed kinetic characterization of the NAD-dependent lactate dehydrogenase from Rhizopus oryzae and to define the nutritional conditions which determine the synthesis of high levels of the enzyme in the mycelium.

\section{METHODS}

Organism and growth conditions. Rhizopus oryzae (IMI 40564) was obtained from the Commonwealth Mycological Institute, Kew, Surrey. Cultures were maintained on potato 
dextrose agar. Mycelia for enzyme studies were grown on a glucose-glutamate-mineral salts medium. The standard medium contained the following constituents $(\mathrm{g} / 1$ distilled water): glucose, $10 \cdot 0$; glutamic acid monosodium salt, $4 \cdot 72 ; \mathrm{KH}_{2} \mathrm{PO}_{4}, \mathrm{I} \cdot 5 ; \mathrm{MgSO}_{4} \cdot 7 \mathrm{H}_{2} \mathrm{O}$, $0.5 ; \mathrm{MnSO}_{4} .4 \mathrm{H}_{2} \mathrm{O}, 0.0005 ; \mathrm{ZnSO}_{4} .7 \mathrm{H}_{2} \mathrm{O}, 0.0005 ;$ ferric citrate, $0.0 \mathrm{I}$. The glucose was autoclaved separately from the other constituents. The final $\mathrm{pH}$ of this medium was $5 \cdot 7$. As indicated later in the paper, higher levels of lactate dehydrogenase could be obtained by increasing the glucose concentration and by lowering the zinc concentration in this medium.

Spore inocula were prepared by washing spores from mycelia grown on glucose-glutamatemineral salts agar with sterile water. Mycelia were grown in $40 \mathrm{ml}$ of medium in $250 \mathrm{ml}$ Erlenmeyer flasks (or in $100 \mathrm{ml}$ of medium in 21 flasks for enzyme purification studies) at $27^{\circ} \mathrm{C}$. The flasks were not shaken. Growth in shallow layers of medium is important for good aerial growth and enzyme yields.

Materials. All biochemicals used in this study were obtained from the Sigma Chemical Company, St Louis, Missouri, U.S.A., with the exception of cycloheximide which was obtained from the Upjohn Company.

Enzyme assays. Mycelia were harvested by filtration, washed thoroughly with distilled water, dried between filter paper and frozen to $-15{ }^{\circ} \mathrm{C}$. The frozen mycelium was ground to a fine powder with a small quantity of $0 \cdot \mathrm{I}$ M-tris- $\mathrm{HCl}$ buffer, $\mathrm{pH} 7 \cdot 4$ (approximately $\mathrm{I} \cdot 5 \mathrm{ml} / \mathrm{g}$ mycelium), in a mortar cooled to $-15{ }^{\circ} \mathrm{C}$. The frozen powder was then thawed rapidly, diluted with twice its volume of cold tris buffer and centrifuged at $12500 \mathrm{~g}$ for $10 \mathrm{~min}$. Very reproducible extraction was obtained by this procedure provided the initial grinding was thorough.

NAD-dependent lactate dehydrogenase was assayed by following the oxidation of NADH at $340 \mathrm{~nm}$ in the reaction mixture: $2.8 \mathrm{ml} 0.1 \mathrm{M}$-phosphate buffer, $\mathrm{pH} 7.2$, containing I $\mu$ mole NADH and $25 \mu$ moles sodium pyruvate plus $0.2 \mathrm{ml}$ enzyme solution, appropriately diluted. The reaction was started by addition of pyruvate after measuring any NADH oxidase in the enzyme solution (usually negligible even in crude extracts).

Alcohol dehydrogenase was similarly assayed in a reaction mixture in which $20 \mu$ moles acetaldehyde were added to start the reaction in place of the pyruvate in the above mixture.

NAD-dependent glutamate dehydrogenase was similarly assayed using the reaction mixture: $2.6 \mathrm{ml} \mathrm{O.I} \mathrm{M-phosphate} \mathrm{buffer,} \mathrm{pH} 7 \cdot 2$, containing I $\mu$ mole NADH plus i $5 \mu$ moles $\mathrm{NH}_{4}{ }^{+}$and $20 \mu$ moles $\alpha$-ketoglutarate plus $0.4 \mathrm{ml}$ enzyme.

Fructose-I,6-diphosphate aldolase was assayed using the following reaction mixture: $2.8 \mathrm{mlo} \cdot \mathrm{I}$ M-tris- $\mathrm{HCl}$ buffer, $\mathrm{pH} 8 \cdot 0$, containing I $\mu$ mole NADH, I unit glycerol-3-phosphate dehydrogenase, $5^{\circ} 6$ units triose phosphate isomerase and $3 \mu$ moles fructose- $\mathrm{I}, 6$-diphosphate plus $0.2 \mathrm{ml}$ enzyme solution. The reaction was started by addition of fructose diphosphate.

For all of the above enzymes $\mathrm{I}$ unit of enzyme activity is defined as the amount of enzyme catalysing the oxidation of I $\mu$ mole of $\mathrm{NADH} / \mathrm{min}$.

The rate of reduction of 3-acetylpyridine adenine dinucleotide $\left(\mathrm{APAD}^{+}\right)$by lactate, catalysed by the Rhizopus oryzae lactate dehydrogenase, was followed at $365 \mathrm{~nm}$ (Kaplan \& Ciotti, 1956) in the following reaction mixture: $2.8 \mathrm{ml} \mathrm{O.I} \mathrm{M-phosphate} \mathrm{buffer,} \mathrm{pH} 7.8$, containing $3 \mu$ moles $\mathrm{APAD}^{+}$and $60 \mu$ moles $\mathrm{L}(+)$-lactate plus $0.2 \mathrm{ml}$ enzyme solution.

Routine enzyme assays used a Unicam SP 800 recording spectrophotometer. A Perkin Elmer 402 spectrophotometer was used for kinetic studies.

Purification of the lactate dehydrogenase. The enzyme could not be highly purified because of its instability even in the presence of substrate and reducing agents. This same difficulty was experienced by Obayashi et al. (I966) who achieved only threefold purification. The following procedure was designed to purify the lactate dehydrogenase to a stage at which 
Table I. Purification of NAD-dependent lactate dehydrogenase from Rhizopus oryzae

$\begin{array}{lcccc}\text { Purification step } & \begin{array}{c}\text { Enzyme } \\ \text { activity } \\ \text { (units) }\end{array} & \begin{array}{c}\text { Protein } \\ (\mathrm{mg})\end{array} & \begin{array}{c}\text { Specific } \\ \text { activity } \\ \text { (units } / \mathrm{mg})\end{array} & \begin{array}{c}\text { Recovery } \\ (\%)\end{array} \\ \text { Crude mycelial extract } & 8 \mathrm{I} 2 & 1670 & 0.49 & 100 \\ 35-55 \%\left(\mathrm{NH}_{4}\right)_{2} \mathrm{SO}_{4} \text { fraction } & 825 & 570 & 1 \cdot 45 & 10 \mathrm{I} \\ \text { After dialysis } & 438 & 570 & 0.77 & 54 \\ \text { Peak fractions from DEAE- } & \mathrm{I} 29 & 25 & 5 \cdot 2 & 16\end{array}$

it was free from both alcohol- and malate-dehydrogenase activity. These two enzymes were present in mycelial extracts at specific activities 5 to Io times greater than the lactate dehydrogenase and are the main dehydrogenases likely to interfere in kinetic studies of the lactate dehydrogenase based on spectrophotometric estimation of NADH oxidation.

Cultures were harvested after $48 \mathrm{~h}$ of growth on $3 \mathrm{l}$ of standard glucose-glutamatemineral salts medium dispensed into 21 Erlenmeyer flasks each containing $100 \mathrm{ml}$ of medium. The mycelium was disrupted as described earlier except that the cold $\mathrm{O} \cdot \mathrm{I}$ M-tris- $\mathrm{HCl}$ buffer, $\mathrm{pH} 7 \cdot 5$, contained $5 \mathrm{~mm}$-mercaptoethanol. All subsequent operations were carried out at $4{ }^{\circ} \mathrm{C}$.

Ammonium sulphate fractionation. Solid ammonium sulphate was slowly added to the crude mycelial extract to bring the solution to $35 \%$ saturation. The suspension was allowed to stand for $\mathrm{I} h$, then the precipitate was removed by centrifugation and discarded. The supernatant contained virtually all of the lactate dehydrogenase activity. Further solid ammonium sulphate was added to the supernatant to bring the solution up to $55 \%$ saturation. After $\mathrm{I} h$ the precipitate was removed by centrifugation. Eighty to $85 \%$ of both malatedehydrogenase and alcohol-dehydrogenase activity remained in the supernatant at this stage whereas the precipitate contained between 80 and $100 \%$ of the lactate dehydrogenase.

The precipitate was dissolved in about $20 \mathrm{ml}$ of $10 \mathrm{~mm}$-tris- $\mathrm{HCl}$ buffer, $\mathrm{pH} 7 \cdot 5$, containing $5 \mathrm{~mm}$-mercaptoethanol and dialysed against three successive 21 volumes of the same buffer allowing $\mathrm{I} \cdot 5 \mathrm{~h}$ in each with constant stirring. Considerable loss of activity occurred during dialysis so this step could not be further prolonged.

$D E A E$ cellulose chromatography. The dialysed extract was applied to a $22 \times 2 \mathrm{~cm}$ column of DEAE cellulose equilibrated with Io mM-tris- $\mathrm{HCl}$ buffer, $\mathrm{pH} 7 \cdot 5$, plus mercaptoethanol. The enzyme was eluted with the same buffer containing an increasing concentration of $\mathrm{NaCl}$ in a linear gradient from 0 to $0.3 \mathrm{M}$. Lactate-dehydrogenase activity was not eluted until the $\mathrm{NaCl}$ concentration reached approximately $0.25 \mathrm{M}$. Malate dehydrogenase was completely eluted before this concentration was reached whereas alcohol dehydrogenase was strongly held by the DEAE cellulose although some was eluted in the later fractions containing lactate dehydrogenase. Only the lactate-dehydrogenase fractions free from alcohol dehydrogenase were used in kinetic studies.

The peak fractions containing lactate dehydrogenase were concentrated by passing through an Amicon XM 50 ultrafilter (mol. wt exclusion limit, 50000). No activity passed through the filtration membrane.

The results of this purification procedure are shown in Table I.

Attempts to purify the enzyme further by a second DEAE cellulose column or by using Sephadex G-200 resulted in almost complete loss of activity. A final purification step by adding ammonium sulphate to the concentrated peak fractions to $50 \%$ saturation, centrifuging and redissolving the precipitate in $10 \mathrm{~mm}$-tris- $\mathrm{HCl}$ buffer, $\mathrm{pH} 7 \cdot 5$, was frequently used but gave no further increase in apparent specific activity. 


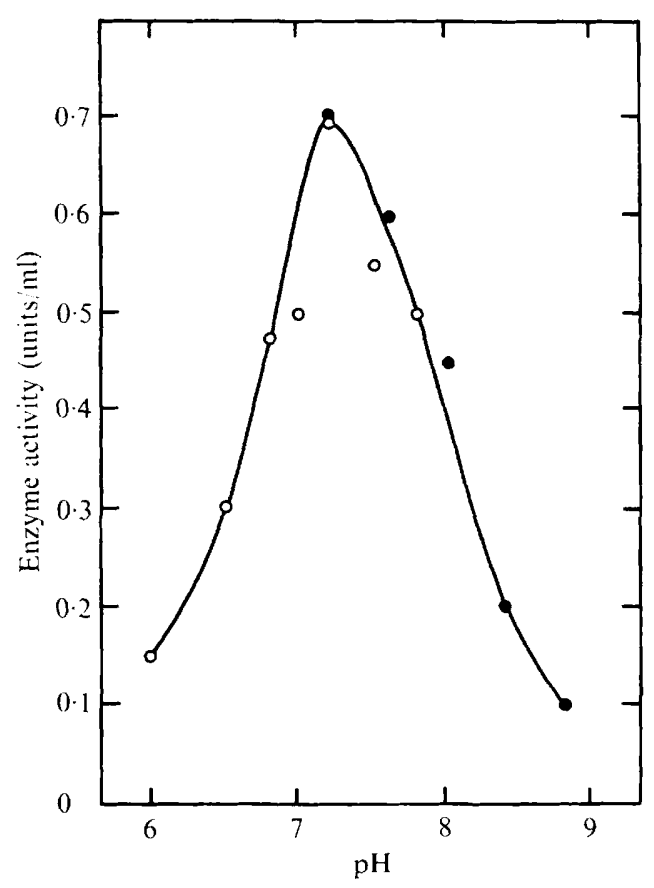

Fig. I. Effect of $\mathrm{pH}$ on lactate dehydrogenase activity. Phosphate buffer $(\mathrm{O}-\mathrm{O})(0 . \mathrm{I} \mathrm{M})$ was used over the $\mathrm{pH}$ range 6.0 to 7.8 and $0 . \mathrm{I} \mathrm{M}$-tris- $\mathrm{HCl}$ buffer $(-)$ over the range $7 \cdot 2$ to 8.8 . The reaction mixture contained $25 \mu$ moles pyruvate, I $\mu$ mole NADH, $0.2 \mathrm{ml}$ enzyme in a total volume of $3.0 \mathrm{ml}$.

Analytical methods. Glucose was estimated by the iodometric method of Somogyi (1945). Protein was estimated by the method of Lowry, Roseborough, Farr \& Randall (195I) with bovine serum albumen as the standard.

Total titratable acidity was determined by titration of samples of the medium with $0.02 \mathrm{M}$ $\mathrm{NaOH}$ with bromocresol purple as indicator (i.e. to an end-point approximating to the initial $\mathrm{pH}$ of the medium). In some experiments lactic acid content was determined by the colorimetric method of Barker \& Summerson (I94I) with $p$-hydroxydiphenyl. The values obtained agreed with total titratable acidity values except in the later stages of growth when total titratable acidity fell more rapidly than did lactic acid as determined by the colorimetric method. However, since lactic-acid determinations were not routinely carried out on all samples, acid content has been reported as total titratable acidity rather than true lactic acid.

\section{RESULTS}

Kinetic properties of the enzyme

pH optimum. Activity was determined over the range 6.0 to 8.6 with $0 \cdot 1$ M-phosphate and tris- $\mathrm{HCl}$ buffers (Fig. I). A well-defined optimum existed at $\mathrm{pH} 7 \cdot 2$.

Effect of pyruvate concentration on activity. Plots of reaction velocity showed normal Michaelis-Menten kinetics with respect to pyruvate concentration (Fig. 2). In this respect the enzyme resembled other fungal lactate dehydrogenases (LeJohn, I97I ; Purohit \& Turian, 1972) and differed from the lactate dehydrogenases from Escherichia coli (Tarmy \& Kaplan, 1968) and from Butyribacterium rettgeri (Wittenberger \& Fulco, 1967) which show a 


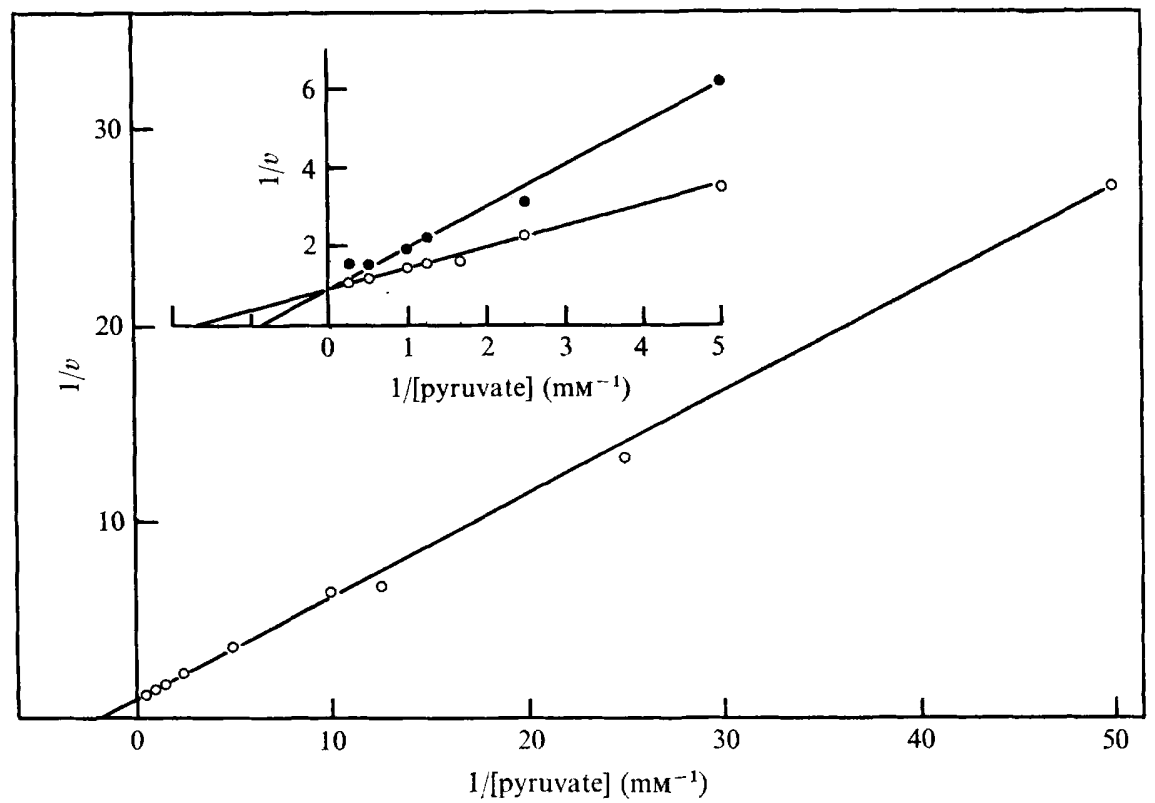

Fig. 2. Effect of pyruvate concentration on enzyme activity and inhibition by $\alpha$-ketobutyrate. Lineweaver-Burk plot of $\mathrm{I} / \mathrm{v}$ against $\mathrm{I} /$ pyruvate concentration $(\mathrm{O}-\mathrm{O})$. Enzyme activity assayed in $0 . \mathrm{I}$ M-phosphate buffer, $\mathrm{pH} \mathrm{7.5}$, containing $0.167 \mathrm{~mm}-\mathrm{NADH}$ at $25^{\circ} \mathrm{C}$. Inset shows effect of $5 \mathrm{~mm}-\alpha$-ketobutyrate on the rate of pyruvate reduction (-)

sigmoidal relationship between pyruvate concentration and enzyme activity, particularly at $\mathrm{pH}$ values above $7 \cdot 0$. The Rhizopus enzyme showed normal hyperbolic saturation kinetics at $\mathrm{pH}$ values of $7 \cdot 2,7 \cdot 5$ and $7 \cdot 8$. It should be noted that the data of Fig. 2 were obtained using an NADH concentration of $0.167 \mathrm{~mm}$ which was well below saturation. It was difficult to study the kinetics spectrophotometrically at saturating NADH concentration because of the low affinity of the enzyme for NADH (see below). The $K_{m}$ value for pyruvate obtained under the above conditions $\left(5.5 \times 10^{-4} \mathrm{M}\right)$ was about $\mathrm{I} / 5$ of the value reported by Obayashi et al. (I966) using 0.067 mM-NADH.

Pyruvate reduction was inhibited by $\alpha$-ketobutyrate. The inhibition was possibly competitive (see Fig. 2) and an apparent $K_{i}$ value of $5 \times 10^{-3} \mathrm{M}$ was obtained using a $5 \mathrm{~mm}$ concentration of the inhibitor. Purohit \& Turian (1972) reported that the Allomyces lactate dehydrogenase was unaffected by 10 $\mathrm{mm}-\alpha$-ketobutyrate.

Effect of NADH concentration on activity. Reaction velocity showed a sigmoidal response to increasing concentrations of NADH up to $3 \times 10^{-5} \mathrm{M}$. Above this concentration the Lineweaver-Burk plot was linear, extrapolating to a fairly high value of $K_{m}$ for NADH of $2.9 \times 10^{-4} \mathrm{M}$ (Fig. 3). When the data were recast as a Hill plot (Fig. 4) the points fell on two lines intersecting at $3 \times 10^{-5} \mathrm{M}$ with a slope of $\mathrm{I} .86$ below this concentration and of $\mathrm{I} \cdot 04$ above it. A similar relationship was found by Tarmy \& Kaplan (I968) for the response of the Escherichia coli lactate dehydrogenase to varying pyruvate concentration. They interpreted their data as indicating the existence of two types of binding site for pyruvate with different affinities for this substrate. One type of binding site with a high affinity for pyruvate is associated with activation of the enzyme; once this is saturated the co-operativity of binding is no longer shown. A similar interpretation would fit the response of the Rhizopus oryzae enzyme to varying NADH concentration. 


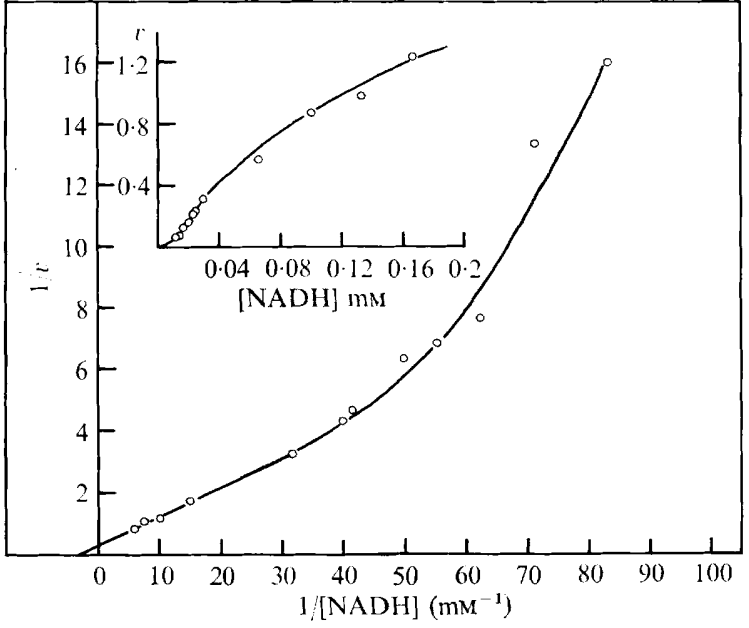

Fig. 3

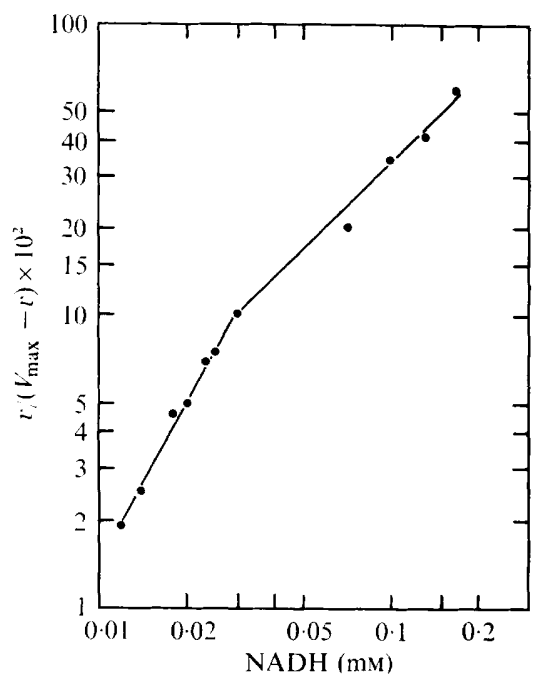

Fig. 4

Fig. 3. Effect of NADH concentration on enzyme activity. Lineweaver-Burk plot of $1 / v$ against I/NADH concentration and direct plot of $v$ against NADH concentration (inset). Enzyme activity assayed in $0^{\circ} \mathrm{I}$ M-phosphate buffer, $\mathrm{pH} 7 \cdot 2$, conteining $\mathrm{I}$ mM-pyruvate at $25^{\circ} \mathrm{C}$.

Fig. 4. Hill plot $\left(\log v /\left(V_{\max }-v\right)\right.$ against $\log \mathrm{NADH}$ concentration) of data shown in Fig. 3. $V_{\max }$ was obtained from the intercept of the Lineweaver-Burk plot on the $1 / v$ axis in Fig. 3 .

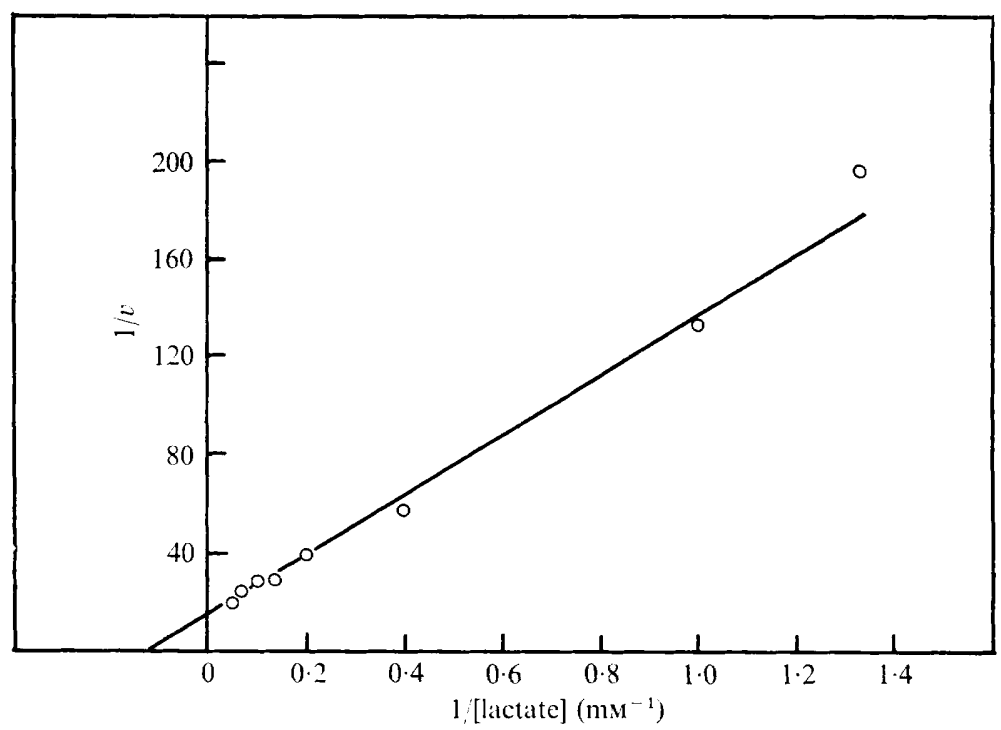

Fig. 5. Effect of $\mathrm{L}(+)$-lactate concentration on the rate of reduction of 3 -acetylpyridine adenine dinucleotide $\left(\mathrm{APAD}^{+}\right)$. Lineweaver-Burk plot of $\mathrm{I} / v$ against $\mathrm{I} /$ lactate concentration. Enzyme activity assayed in $0.1 \mathrm{M}$-phosphate buffer, $\mathrm{pH} 7 \cdot 8$, containing I $\mathrm{mM}-\mathrm{APAD}^{+}$at $25{ }^{\circ} \mathrm{C}$.

Oxidation of lactate to pyruvate by using 3-acetylpyridine adenine dinucleotide $\left(A P A D^{+}\right)$ as hydrogen acceptor. The Rhizopus oryzae enzyme shares with the bacterial lactate dehydrogenases from Escherichia coli and Butyribacterium rettgeri its inability to catalyse the oxidation of lactate by $\mathrm{NAD}^{+}$even at high concentrations of lactate and $\mathrm{NAD}^{+}$and at 


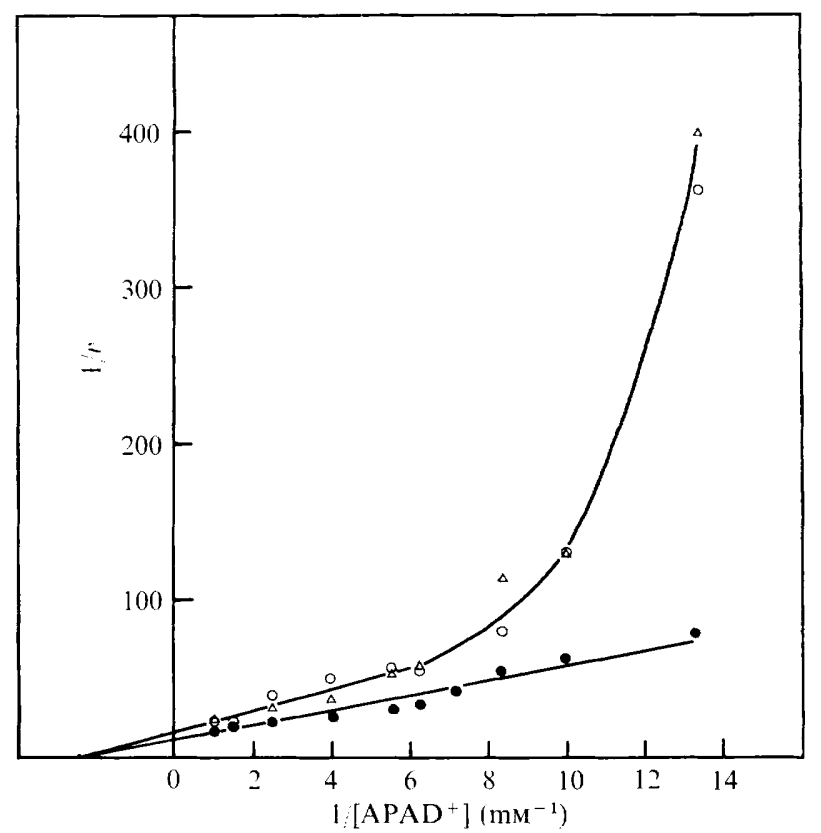

Fig. 6. Effect of $\mathrm{APAD}^{+}$concentration on the rate of $\mathrm{APAD}^{+}$reduction in the presence and absence of $\mathrm{NAD}^{+}$. Lineweaver-Burk plot of $\mathrm{I} / v$ against $\mathrm{I} / \mathrm{APAD}^{+}$concentration $\left(\mathrm{O}_{-}-\mathrm{O}\right)$ and in the

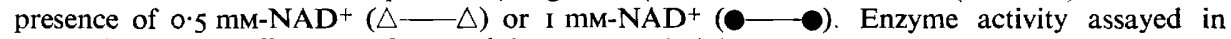
$0 \cdot \mathrm{I}$ M-phosphate buffer, $\mathrm{pH} 7 \cdot 8$, containing $20 \mathrm{mM}-\mathrm{L}(+)$-lactate.

high $\mathrm{pH}$ values. However, like the $\mathrm{D}(-)$-lactate dehydrogenase of $B$. rettgeri (Wittenberger, I966), it would readily catalyse the reduction of $\mathrm{APAD}^{+}$by lactate. The $R$. oryzae lactate dehydrogenase would use only $\mathrm{L}(+)$-lactate as substrate and showed no activity toward $\mathrm{D}(-)$-lactate. The relationship between the rate of $\mathrm{APAD}^{+}$reduction and the concentration of lactate followed normal Michaelis-Menten kinetics (Fig. 5). The $K_{m}$ for lactate at $\mathrm{pH} 7 \cdot 8$ and I mM-APAD + was $8 \cdot 3 \times \mathrm{IO}^{-3} \mathrm{M}$.

The relationship between the rate of oxidation of lactate and $\mathrm{APAD}^{+}$concentration was sigmoidal at $\mathrm{APAD}^{+}$concentrations below $\mathrm{I} \cdot 5 \times \mathrm{IO}^{-4} \mathrm{M}$ (Fig. 6). Above this concentration the Lineweaver-Burk plot was linear giving a $K_{m}$ value on extrapolation of $4.2 \times 10^{-4} \mathrm{M}$ $\mathrm{APAD}^{+}$. The effect of $\mathrm{NAD}^{+}$on the rate of $\mathrm{APAD}^{+}$reduction was interesting (Fig. 6). In the case of the Butyribacterium rettgeri lactate dehydrogenase, NAD $\mathrm{N}^{+}$at $3 \times 10^{-4} \mathrm{M}^{2}$ acts as a competitive inhibitor of $\mathrm{APAD}^{+}$reduction showing that it does bind to the enzyme at the same site as $\mathrm{APAD}^{+}$even though it cannot be reduced by lactate (Wittenberger, 1966). With the Rhizopus oryzae enzyme, $\mathrm{NAD}^{+}$at a concentration of $5 \times 10^{-4} \mathrm{M}$ had no effect on the rate of $\mathrm{APAD}^{+}$reduction. At $\mathrm{IO}^{-3} \mathrm{M}, \mathrm{NAD}^{+}$stimulated the rate of $\mathrm{APAD}^{+}$reduction and abolished the co-operativity of binding shown by the enzyme at low $\mathrm{APAD}^{+}$concentrations.

\section{Nutritional factors determining the level of lactate dehydrogenase activity in the mycelium}

Effect of glucose concentration. Lactate-dehydrogenase level and its relationship to growth, acid production and glucose utilization at four different glucose concentrations is shown in Fig. 7. On the glucose-glutamate-mineral salts medium used, maximum growth yield 


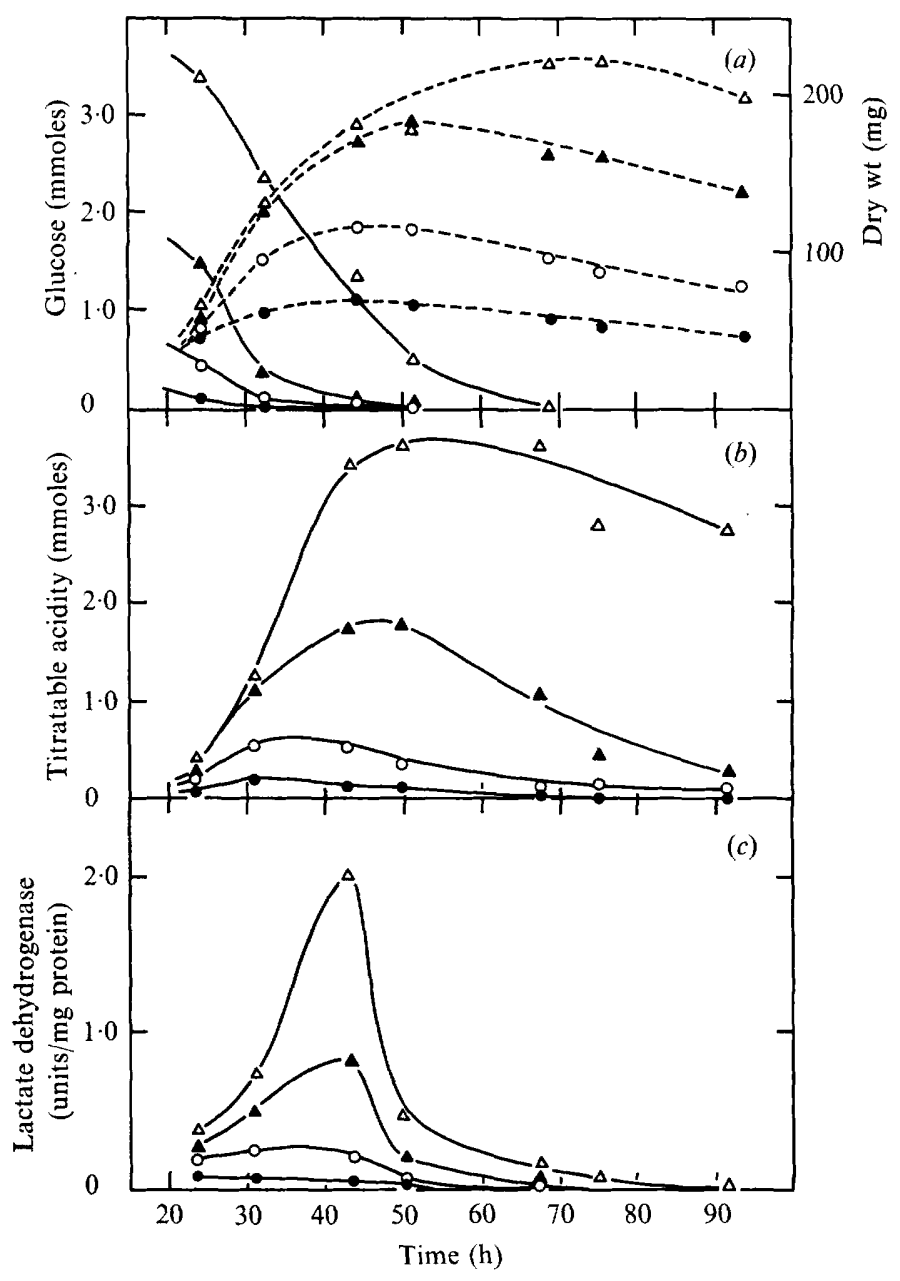

Fig. 7. Effect of glucose concentration on growth, acid production and lactate dehydrogenase activity. Mycelia grown in glucose-glutamate-mineral salts medium containing initial glucose concentrations of $2 \%(\triangle) ; \mathrm{I} \%(\mathbf{\Delta}) ; 0.5 \%(O) ; 0.25 \%(\Theta) .(a)$ Changes in dry weight (broken line) and glucose content of the medium (continuous line). (b) Changes in titratable acidity of the medium (largely due to lactic acid). (c) Changes in lactate dehydrogenase activity.

increased in proportion to glucose concentration up to $1 \%$ glucose. An increase in the glucose concentration from $\mathrm{I}$ to $2 \%$ only increased the maximum dry weight reached by $20 \%$, although it delayed the onset of sporulation and the accompanying decline in dry wt (Fig. 7a). Lactate dehydrogenase level showed a different response to increasing glucose concentration (Fig. 7 c). At 0.25 and $0.5 \%$ glucose the lactate-dehydrogenase activity of the mycelium was very low and declined rapidly after $3 \mathrm{I} \mathrm{h}$. In I \% glucose, lactate-dehydrogenase activity increased up to $43 \mathrm{~h}$ reaching a maximum level which was 4 times the level reached in $0.5 \%$ glucose, while in $2 \%$ glucose the maximum level of activity was nearly 9 times that reached in $0.5 \%$ glucose. At all four glucose concentrations the maximum lactate dehydrogenase level was reached during the phase of active vegetative growth and rapid glucose utilization. Activity declined sharply towards the end of the rapid growth phase. Acid 
Table 2. Effect of glucose concentration on enzyme activities in Rhizopus oryzae

Specific activities of lactate dehydrogenase, alcohol dehydrogenase and fructose-I,6-diphosphate aldolase in 43 -h-old cultures grown on glucose-glutamate-mineral salts media of differing initial glucose concentrations.

$\begin{array}{cccc}\begin{array}{c}\text { Glucose } \\ \begin{array}{c}\text { concentration } \\ (\%, \mathrm{w} / \mathrm{v})\end{array}\end{array} & \begin{array}{c}\text { Lactate } \\ \text { dehydrogenase }\end{array} & \begin{array}{c}\text { Alcohol } \\ \text { dehydrogenase }\end{array} & \begin{array}{c}\text { Fructose-I,6- } \\ \text { diphosphate aldolase }\end{array} \\ 0.25 & 0.05 & 3.2 & \text { Not determined } \\ 0.50 & 0.16 & 5.3 & 0.38 \\ 1.00 & 0.83 & 2.3 & 0.33 \\ 2.00 & 2.00 & 2.5 & 0.31\end{array}$

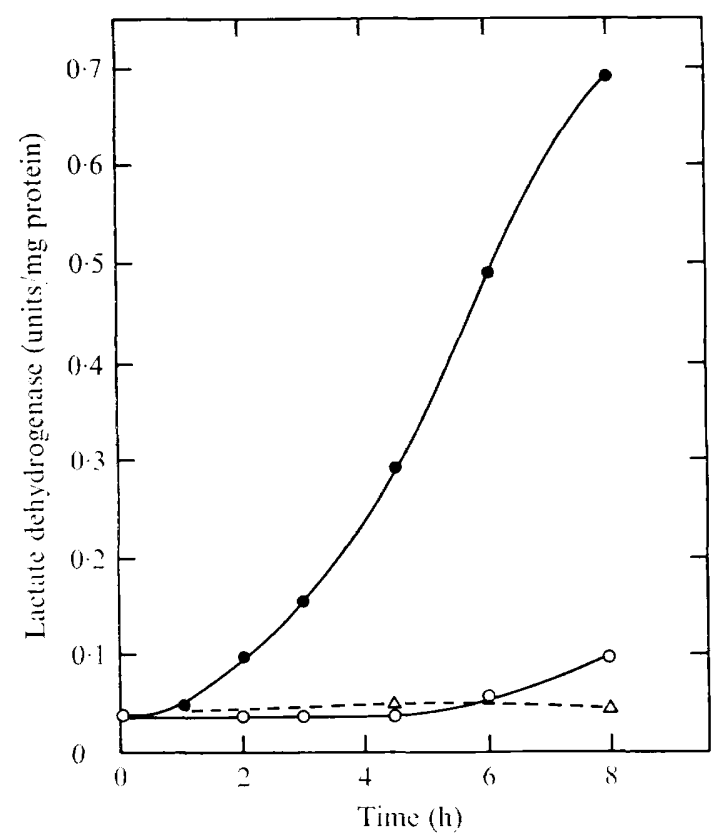

Fig. 8. Changes in lactate dehydrogenase activity following transfer of 48 -h-old mycelial pads from a $2 \%$ glycerol-glutamate-mineral salts medium to a $2 \%$ glucose-glutamate-mineral salts medium. Lactate dehydrogenase activity of cultures transferred to glucose medium (- $)$; to a glucose medium containing $10 \mu \mathrm{g} / \mathrm{ml}$ cycloheximide $(\mathrm{O}-\mathrm{O})$; and cultures remaining on the glycerol medium $(\triangle---\triangle)$.

production reflected these differences in the level of lactate dehydrogenase activity at the four glucose concentrations (Fig. $7 b$ ).

The large differences in lactate dehydrogenase activity may be contrasted with the relative alcohol dehydrogenase and fructose diphosphate aldolase levels. Table 2 shows the relative activities of the three enzymes in 43 -h-old mycelia at the different glucose concentrations. The level of aldolase was virtually unaffected by the glucose content of the medium; for alcohol dehydrogenase, maximum activity occurred in $0.5 \%$ glucose and was considerably less at the two higher glucose concentrations.

The nature of the carbon source is important as well as its concentration. On I \% glycerol the specific activity of lactate dehydrogenase did not rise above 0.06 units $/ \mathrm{mg}$ protein, 


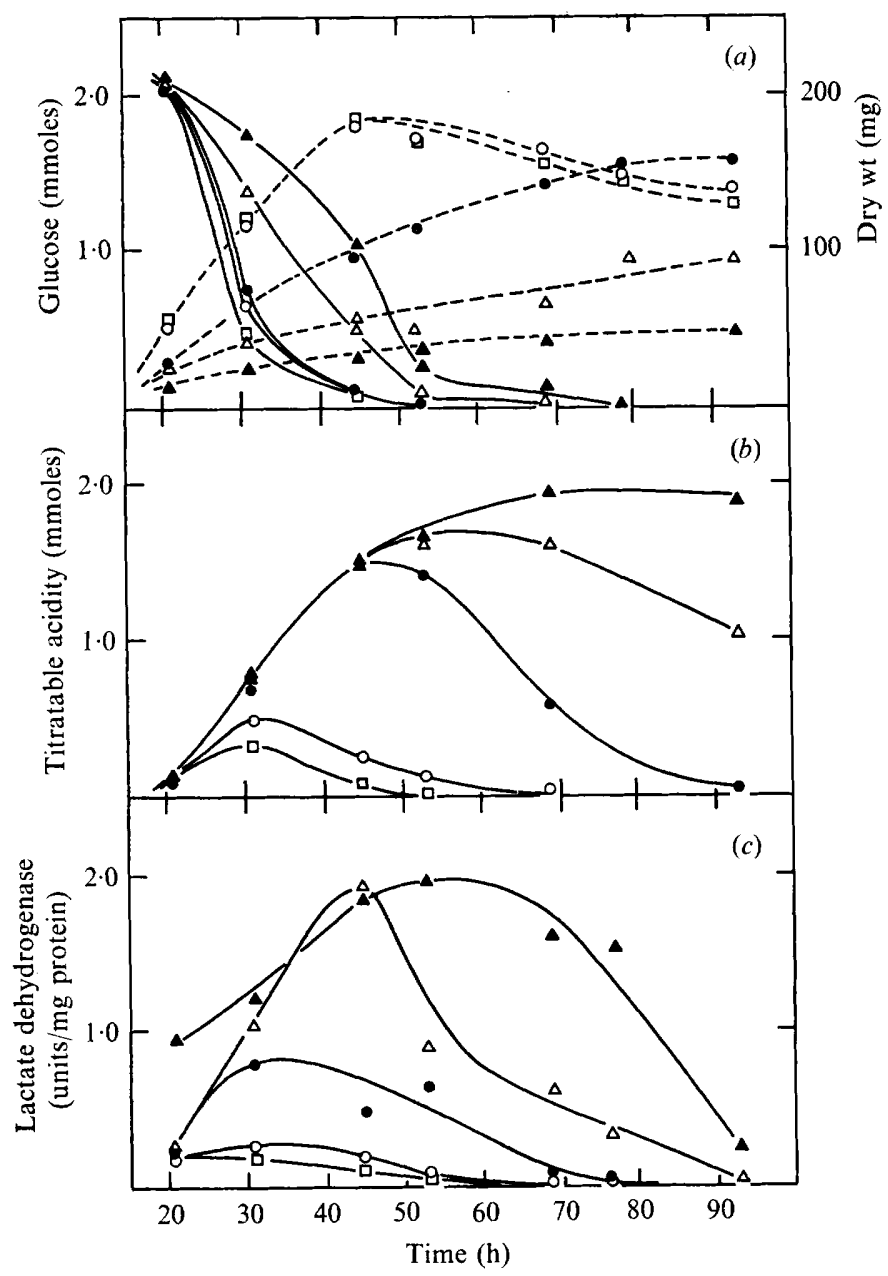

Fig. 9. Effect of zinc concentration in the growth medium on growth, acid production and lactatedehydrogenase activity. Mycelia grown on I \% glucose-glutamate-mineral salts media containing initial concentrations of zinc of $0.34 \mu_{\mathrm{M}}(\Delta) ; 0.86 \mu \mathrm{M}(\triangle) ; \mathrm{I} \cdot 72 \mu_{\mathrm{M}}(\mathbf{O}) ; 4 \cdot 3 \mu \mathrm{M}(\mathrm{O}) ; \mathrm{I} 7 \cdot 2 \mu \mathrm{M}(\square)$. (a) Changes in dry wt (broken line) and glucose content of the medium (continuous line). (b) Changes in titratable acidity of the medium. (c) Changes in lactate-dehydrogenase activity.

whereas on $\mathrm{r} \%$ galactose the specific activity at $43 \mathrm{~h}$ was $0.58 \mathrm{unit} / \mathrm{mg}$ protein which is similar to the level attained on $\mathrm{I} \%$ glucose.

Induction of lactate dehydrogenase activity by high glucose concentration. Changes in lactate dehydrogenase level were followed when mycelia, grown for $48 \mathrm{~h}$ on a $2 \%$ glycerol medium, were transferred to a $2 \%$ glucose medium (Fig. 8). A significant increase in lactate dehydrogenase activity was detected after $2 \mathrm{~h}$ and after $8 \mathrm{~h}$ the activity was 15 times the level in mycelia remaining on the glycerol medium and was approaching the maximum level found in mycelia grown throughout on $2 \%$ glucose. The presence of the protein synthesis inhibitor, cycloheximide, at $10 \mu \mathrm{g} / \mathrm{ml}$ completely inhibited the increase in lactate dehydrogenase on $2 \%$ glucose for $4 \mathrm{~h}$ after transfer and only a small increase was detectable between 4 and $8 \mathrm{~h}$. This suggested that the increase in lactate dehydrogenase was due to de novo synthesis of enzyme after transfer to the glucose medium. 
Table 3. Effect of zinc concentrations on enzyme activities in Rhizopus oryzae

Specific activities of lactate dehydrogenase, alcohol dehydrogenase and NAD-dependent glutamate dehydrogenase in 45 -h-old cultures grown on glucose (1\%)-glutamate-mineral salts medium containing different concentrations of zinc.

Zinc
concentration
$(\mu$ moles $/ 1)$
0.34
0.86
$1 \cdot 72$
4.30
$17 \cdot 20$

\begin{tabular}{ccc}
\multicolumn{3}{c}{ Specific activity (units/mg protein) } \\
$\begin{array}{c}\text { Lactate } \\
\text { dehydrogenase }\end{array}$ & $\begin{array}{c}\text { Alcohol } \\
\text { dehydrogenase }\end{array}$ & $\begin{array}{c}\text { Glutamate } \\
\text { dehydrogenase }\end{array}$ \\
1.82 & 8.00 & 0.035 \\
1.96 & 8.15 & 0.053 \\
0.47 & 5.75 & 0.058 \\
0.20 & 6.50 & 0.045 \\
0.10 & 18.90 & 0.045
\end{tabular}

Effect of zinc concentration in the growth medium on lactate dehydrogenase level. The importance of zinc concentration in determining the proportion of carbohydrate converted to lactic acid by Rhizopus has been emphasized by Foster (I949). Concentrations of zinc which limit growth lead to increased yields of lactic acid.

Growth, acid accumulation and lactate dehydrogenase activity at 5 different concentrations of zinc are shown in Fig. 9. On the I \% glucose medium used, the three lower concentrations of zinc were clearly growth-limiting (Fig. 9a). In accordance with the above principle, considerable acid accumulated at these three zinc levels while at the two highest levels only a small and transient amount of acid accumulated (Fig. 9b). Zinc concentration had a striking effect also on the specific activity of lactate dehydrogenase in the mycelium (Fig. 9c). At the lowest zinc concentration $(0.34 \mu \mathrm{M})$ a high level of lactate dehydrogenase was maintained for the first $75 \mathrm{~h}$ of growth. Glucose was utilized much more slowly at this zinc concentration and no sporulation was evident at $93 \mathrm{~h}$. At $0.86 \mu \mathrm{M}$-zinc, lactate dehydrogenase activity reached a similar high level after $45 \mathrm{~h}$ but this then rapidly decreased to a low level. Sporulation was evident at $76 \mathrm{~h}$. Higher concentrations of zinc resulted in considerably lower lactate dehydrogenase levels, increased rates of glucose utilization and earlier sporulation ( 53 to $65 \mathrm{~h}$ ). Although little difference in the rate of glucose utilization was evident between $\mathrm{I} \cdot 72$ and $\mathrm{I} 7 \cdot 2 \mu \mathrm{M}$-zinc, considerable differences in lactate dehydrogenase level and acid accumulation were apparent between $\mathrm{I} \cdot 72$ and $4 \cdot 3 \mu \mathrm{M}$-zinc.

In contrast to lactate dehydrogenase, alcohol-dehydrogenase and NAD-dependent glutamate-dehydrogenase activities do not differ greatly in mycelia grown at the five different zinc concentrations except that alcohol-dehydrogenase activity was considerably higher at the highest zinc concentration (Table 3). This was somewhat surprising as these two enzymes are known to be zinc-containing proteins in other organisms (Vallee, 1959).

\section{DISCUSSION}

In discussing the properties of the lactate dehydrogenase from Allomyces, Purohit \& Turian (1972) pointed out that bacterial lactate dehydrogenases from Escherichia coli and Butyribacterium rettgeri have multiple binding sites for pyruvate whereas the fungal lactate dehydrogenases which have been studied so far, from Pythium debaryanum (LeJohn, 1971) and Allomyces, possess multiple binding sites for NADH. The Rhizopus oryzae lactate dehydrogenase appears to fit into this general pattern although it is the only L-lactate dehydrogenase among the above enzymes; all the others are D-lactate dehydrogenases. The transition from sigmoidal to hyperbolic kinetics at relatively low concentrations of both 
$\mathrm{NADH}$ and $\mathrm{APAD}^{+}$suggests the existence of two types of binding site with different affinities for the coenzyme. The failure of $\mathrm{NAD}^{+}$to inhibit the reduction of $\mathrm{APAD}^{+}$by lactate (cf. Wittenberger, I966) suggests that $\mathrm{NAD}^{+}$did not readily bind to the catalytic coenzyme site. However, the activation of $\mathrm{APAD}^{+}$reduction by high $\mathrm{NAD}^{+}$concentrations may have been due to $\mathrm{NAD}^{+}$binding (albeit with a low affinity) to an allosteric site.

As well as the control of enzyme activity exercised by NADH, the amount of lactate dehydrogenase in the mycelium is determined by the composition of the medium, especially the availability of glucose (or other rapidly metabolizable carbohydrate). The data suggest that when the supply of glucose is in excess of the requirements of the assimilatory processes of the fungus, the high endogenous concentration of glucose (or more probably of some metabolite derived from glucose) favours the synthesis of lactate dehydrogenase. An alternative interpretation is that glucose represses the synthesis of enzymes catalysing the inactivation or degradation of lactate dehydrogenase. Such enzymes may be responsible for the rapid decrease in lactate dehydrogenase activity which occurs before sporulation. However, the timing of the decrease is the same on I and $2 \%$ glucose (Fig. 7) but sporulation is markedly delayed by the higher glucose concentration and the inhibition by cycloheximide of the increase in lactate dehydrogenase activity after transfer of mycelia from a glycerol medium to a $2 \%$ glucose medium also suggests an induced synthesis on high glucose media.

The well-established relationship between zinc concentration and acid production (Foster, 1949) can be similarly interpreted. At growth-limiting levels of zinc, lactate dehydrogenase synthesis is favoured since, under such conditions, glucose is present in excess of the requirements of assimilatory processes. It does not necessarily follow that the reduction of any of the nutrients, other than glucose, to growth-limiting levels will produce the same effect since the concentration of the metabolite which mediates the 'glucose effect' may be specifically sensitive to the concentration of zinc. Thus the ratio of glucose concentration to zinc concentration is possibly the critical determinant in the induction process.

The control of lactic acid production in Rhizopus oryzae can be related to the factors controlling the synthesis and activity of lactate dehydrogenase. The relatively low affinity for NADH and the co-operative binding of NADH by the enzyme ensures that pyruvate is converted to lactate only when the rate of NADH generation due to glycolysis exceeds the capacity of other re-oxidizing systems to regenerate $\mathrm{NAD}^{+}$. The control of enzyme synthesis will also prevent diversion of pyruvate to lactate except when glucose is present in excess of the growth requirements of the fungus. The results are consistent with the general concept of 'shunt metabolism' proposed by Foster (I949) to account for the accumulation of organic acids by fungi at high carbohydrate concentrations. However, Foster envisaged that diversion of intermediates into a shunt pathway occurred simply as a result of substrate-saturation of an enzyme catalysing a rate-limiting step in the 'normal' pathway. It is evident from the results presented here that a more complex regulatory system operates to control lactic acid production. It would be of interest to determine whether comparable controls exist in fumaric acid-forming strains of Rhizopus. The existence of 'shunt or overflow' metabolism implies that the control of carbohydrate catabolism at earlier stages of glycolysis may be different from that in other organisms and poses the problem of its functional significance.

The technical assistance of Miss Merle Richardson is gratefully acknowledged. 


\section{REFERENCES}

BARKer, S. B. \& Summerson, W. H. (1941). The colorimetric determination of lactic acid in biological material. Journal of Biological Chemistry 138, 535-554.

Foster, J. W. (1949). Chemical Activities of Fungi. New York: Academic Press,

Gleason, F. H., Nolan, R. A., Wilson, A. C. \& Emerson, R. (1966). D(-)Lactate dehydrogenase in lower fungi. Science, New York 152, I 272-I 273.

Gleason, F. H. \& Price, J. S. (1969). Lactic acid fermentation in lower fungi. Mycologia 6r, 945-956.

Kaplan, N. O. \& CrotT, M. M. (1956). Chemistry and properties of the 3-acetylpyridine analogue of diphosphopyridine nucleotide. Journal of Biological Chemistry 221, 823-832.

LEJOHN, H. B. (I97I). D(-)Lactate dehydrogenases in fungi. Journal of Biological Chemistry 246, 2 I 1 6-2 I.26.

Lowry, O. H., Roseborough, N. J., FarR, A. L. \& Randall, R. J. (1951). Protein measurement with Folin phenol reagent. Journal of Biological Chemistry 193, 265-275.

Obayashi, A., Yorifugi, H., Yamagata, T., IJichi, T. \& Kanie, M. (1966). Respiration in organic acidforming molds. Part I. Purification of cytochrome $c$, coenzyme $\mathrm{Q}_{9}$ and L-lactic dehydrogenase from lactate-forming Rhizopus oryzae. Agricultural and Biological Chemistry 30, 717-724.

Pritchard, G. G. (I97I). An NAD ${ }^{+}$-independent L-lactate dehydrogenase from Rhizopus oryzae. Biochimica et biophysica acta 250, 25-34.

Purohit, K. \& Turian, G. (1972). D(-)Lactate dehydrogenase from Allomyces. Archiv fuir Mikrobiologie 84, 287-300.

Somogyi, M. (1945). Determination of blood sugar. Journal of Biological Chemistry 160, 69-73.

TARMY, E. M. \& KAPLAN, N. O. (1968). Kinetics of Escherichia coli B D-lactate dehydrogenase and evidence for a pyruvate controlled change in conformation. Journal of Biological Chemistry 243, 2587-2596.

VALLEE, B. L. (1959). Biochemistry, physiology and pathology of zinc. Physiological Reviews 39, 443-490. WitTenBerger, C. L. (1966). Unusual kinetic properties of a DPN-linked lactate dehydrogenase from Butyribacterium rettgeri. Biochemical and Biophysical Research Communications 22, 729-736.

Wittenberger, C. L. \& Fulco, J. G. (1967). Purification and allosteric properties of a nicotinamide adenine dinucleotide linked $\mathrm{D}(-)$ specific lactate dehydrogenase from Butyribacterium rettgeri. Journal of Biological Chemistry 242, 2917-2924. 